Marquette University

e-Publications@Marquette

Finance Faculty Research and Publications

Finance, Department of

4-1-2012

\title{
Firm Location and Corporate Debt
}

Matteo Arena

Marquette University, matteo.arena@marquette.edu

Michael Dewally

Marquette University, michael.dewally@marquette.edu

Accepted Version. Journal of Banking \& Finance, Vol. 36, No. 4 (April, 2012): 1079-1092. DOI. (C) 2012 Elsevier. Used with permission.

NOTICE: this is the author's version of a work that was accepted for publication in Journal of Banking and Finance. Changes resulting from the publishing process, such as peer review, editing, corrections, structural formatting, and other quality control mechanisms may not be reflected in this document. Changes may have been made to this work since it was submitted for publication. A definitive version was subsequently published in Journal of Banking and Finance, VOL 36, ISSUE 4, (April 2012). DOI. 


\title{
Firm location and corporate debt
}

\author{
Matteo P. Arena ${ }^{a}$, Michaël Dewally ${ }^{b *}$
}

${ }^{a}$ Marquette university, finance department, Milwaukee, WI, USA

${ }^{\mathrm{b}}$ Towson university, department of finance, Towson, MD, USA

This version: October 31, 2011

Journal of Banking and Finance, forthcoming

\begin{abstract}
This study examines the influence of a firm's geographical location on corporate debt and provides evidence that the higher cost of collecting information on firms distant from urban areas has significant implications on a wide array of corporate debt characteristics. We find that rural firms face higher debt yield spreads and attract smaller and less prestigious bank syndicates than urban firms. Rural firms attempt to reduce their informational disadvantage by relying more on relationship banking. Our results on the effect of location on corporate debt are robust to the inclusion of an extensive set of firm and issue characteristics.
\end{abstract}

JEL classification: G32; G21; G24

Keywords: Corporate location; Debt underwriting; Cost of debt; Debt maturity; Capital structure

E-mail addresses: matteo.arena@mu.edu (Matteo P. Arena), mdewally@ towson.edu (Michaël Dewally)

We thank an anonymous referee, Ike Mathur (the editor), Sarah Peck, Emre Unlu, and participants to the 2010 Annual Meeting of the Financial Management Association for helpful comments and suggestions. 


\section{Introduction}

Several studies document a significant interplay between geographical location and equity investing showing that distance, with its informational implications, leads to differences in the degree of equity investing and issuance. ${ }^{1}$ The finance literature, however, provides so far limited insight on the effect of firm location on the debt side of capital markets. In this study we examine for the first time the effect of a firm's distance from large urban areas on a wide array of corporate debt characteristics. Our analysis expands our current understanding of the geographical segmentation of debt markets and how this segmentation affects corporate debt policy. We find that the informational disadvantage faced by rural firms significantly increases their cost of debt and prevents them to attract a large number of prestigious underwriting and lending syndicate banks. Rural and small city firms try to mitigate the effect of geographical distance on debt costs by relying more on relationship banking. Distance, however, has no significant effect on leverage and only a limited effect on debt maturity.

Fewer institutional debt investors and banks are located in rural areas, which we define to be at least 100 miles from the center of any metropolitan area of 1,000,000 or more people. Institutional debt investors, commercial and investment banks might preferentially invest in, lend to, and better monitor urban firms. Our main hypothesis is based on the effect that the informational disadvantage faced by rural firms has on the cost of debt. If banks and institutional debt investors monitor rural companies less intensively for proximity reasons and analysts' research is not as plentiful and of lower quality, debtholders will impose higher yields

\footnotetext{
${ }^{1}$ Investors favor equity investments in local firms (Coval and Moskowitz (1999) and Grinblatt and Keloharju (2001)). Fewer investors trade, fewer analysts cover, and fewer institutions own rural firms than urban firms (Loughran and Schultz (2005)). Analysts are more accurate when they cover geographically proximate firms (Malloy (2005)). Rural firms are less likely to issue seasoned equity than urban firms (Loughran (2008)).
} 
to compensate for higher risk of asset substitution. Consistent with our proximity hypothesis, we show that debt of rural debt is characterized by higher spreads, everything else constant. In the primary market, we find that rural firms face higher spreads than comparable urban firms. Rural firms pay about 9 basis points over their urban counterparts. This difference in debt costs corresponds approximately to a present value of additional annual interest expenses of about $\$ 70$ million for the average firm in our sample.

Rural companies might differ from urban companies in their debt-related decisions because of supply side constraints. We posit that proximity may influence the structure of debt underwriting and lending syndicates. If there is less interest and competition to underwrite, lend and invest in rural firms, prestigious banks will be less likely to arrange debt deals for rural firms. In addition, underwriting and loan syndicates should be significantly smaller for rural firms' debt. Consistent with this conjecture, we find that bank syndicates which lend and underwrite debt for rural firms are significantly smaller and less prestigious than syndicates which arrange debt for urban firms.

The enhanced monitoring offered by relationship banking may attenuate the informational disadvantage faced by borrowing rural firms. Brickley et al. (2003) show that smaller rural firms are more likely to forge strict relationships with regional banks than other firms. Dass and Massa (2011) and Hauswald and Marquez (2006) show that banks are able to receive more precise signals about a borrowing firm's quality when the distance between the lending institution and the borrower is shorter. Renegotiations, typical of relationship lending, are usually based on "soft" information that "cannot be verifiably documented in a report that the loan officer can pass on to his superiors" (Berger et al. (2005)). We therefore expect rural firms to borrow more from local banks and repeatedly borrow from the same banks instead of 
frequently changing lenders. Consistent with our conjecture, we find that, even after controlling for other firm characteristics related to credit quality, rural and small city firms are more likely to borrow from non-urban banks and that rural banks rely more on relationship banking and recurrently borrow from the same banks.

In the last section of the paper we examine the effect of firm location on the structure of corporate debt by focusing on leverage and debt maturity. We empirically obtain our result on firm location and debt maturity by accounting for the simultaneous choice of leverage and debt maturity as in Johnson (2003) and Datta et al. (2005) because, as documented by Barclay et al. (2003), firms endogenously choose leverage and debt maturity. After controlling for the endogenous relation between leverage and debt maturity and other firm characteristics, we find that rural and urban firms carry debt with similar maturity and leverage in our most complete specification which includes year and industry dummies. The significant difference in debt costs that we observe between urban and rural firms is not inconsistent with the non-significant difference in leverage. Along with debt, equity is more expensive for rural than urban firms, as documented by Loughran (2008). The evidence provided by our study complements the findings of studies of the effect of proximity on firms' equity suggesting that rural firms cannot easily shift capital from debt to equity (or vice versa from equity to debt) to reduce their cost of capital.

All our results on the influence of location on debt underwriter prestige, syndicate size, debt maturity, and yield are robust to the inclusion of an extensive set of firm characteristics. Our multivariate analysis provides strong evidence that location has a significant incremental effect on these debt characteristics over an extensive set of variables that the literature finds related to corporate debt choices (e.g., firm size, profitability, fixed assets, capital expenditures, credit ratings). 
Our results, as the great majority of studies in corporate finance, are based on a sample of publicly traded firms. Our empirical analysis, therefore, does not consider a large group of smaller, private firms that are located in rural areas. We expect problems associated with information asymmetry and limited access to capital to be even stronger for private rural firms. If anything, restricting our sample to public companies, could potentially bias our tests against finding a significant effect of location on corporate debt decisions. It is also important to notice that the results of this study do not imply that rural firms are sub-optimally located far from large financial centers and should move their headquarters to reduce debt costs. Debt cost implications are only one of many factors a firm has to consider when selecting the location of its headquarters. Rural firms might favor their location because of industry geographical clustering, proximity to suppliers or customers (Krugman (1991)), state tax considerations (Papke (1991)), or local favoritism by public officials (Bebchuk and Cohen (2003)).

The rest of the paper is structured as follow. Section 2 presents our hypotheses. Section 3 describes our data and sample. We report our univariate and multivariate results in Sections 4 and 5. Section 6 contains additional tests and robustness checks. Section 7 concludes the study.

\section{The effect of firm's location on corporate debt policy: Hypotheses}

In this section we further develop the research questions which guide our empirical investigation of the impact of firm's location on corporate debt. These questions focus on how distance from urban areas affects debt yields, debt syndicate structure, corporate leverage, and debt maturity. 


\subsection{The effect of firm's location on the cost of debt}

The proximity hypothesis: Companies with higher risk of asset substitution endure a higher cost of debt (Leland and Pyle (1977)). If, everything else constant, banks monitor rural companies less intensively because of geographical distance and analysts' research is not as

plentiful and of lower quality, debt-holders might impose higher yields on rural firms to compensate for higher risk of asset substitution. We conjecture that, ceteris paribus, on average the yield of debt issued by rural firms is higher than the yield of debt issued by urban firms.

The monitoring hypothesis: If banks and institutional bond investors monitor rural companies more intensely and frequently to reduce information asymmetry problems such as the risk of asset substitution, the yield of debt raised by rural firms should not significantly differ from the yield of debt raised by urban firms.

2.2. The effect of firm's location on lending and underwriting bank syndicates, and relationship banking

Similar to equity institutional investors, debt investors, debt underwriters and banks are for the most part concentrated in urban areas. Even though the distance between borrowing firms and their banks is increasing, bank lending is still principally local (Petersen and Rajan (2002), Becker (2007)). Investment bank and commercial bank debt analysts and underwriters therefore should be more likely to underwrite debt, negotiate loans and monitor urban companies for which it is easier and more cost effective to collect information because of proximity reasons. Proximity to urban areas should, therefore, have a direct effect on the number of banks forming bond underwriting and lending syndicates. We expect rural firms to be less likely to attract large bank syndicates. 
Additionally, proximity to urban areas should also affect the reputation level of the lending and underwriting institutions. Similar to what Loughran (2008) establishes for equity underwriting, remoteness from urban areas should lessen the competition to lend or underwrite rural firms' debt offering resulting in a less prestigious bank leading the issue. Information considerations can also influence the effect of urban proximity on lending and underwriting bank prestige. Prestigious underwriters are known to possess quality information as shown by Fang (2005); yet, the remoteness of rural firms reduce the informational advantage of prestigious underwriters. As such, the informational advantage of prestigious underwriters is lower for rural firms and would result in a less fully informed position when making the underwriting or lending decision. On the other hand, some of the less prestigious underwriters that might be located in rural and small city areas might principally work with rural firms for which they have an informational advantage, a phenomenon similar to that observed for municipal bond offerings in Butler (2008). We conjecture that, ceteris paribus, on average more reputable banks are less likely to underwrite debt and lend to rural firms and that rural and small city firms are more likely to rely on relationship banking with local banks to reduce their informational disadvantage.

\subsection{The effect of firm's location on debt maturity and leverage}

The proximity hypothesis: Shorter-term debt requires frequent renegotiations and monitoring from banks (Diamond (1991)). Dass and Massa (2011) and Hauswald and Marquez (2006) posit that banks and other institutional debt investors are likely to monitor more easily proximate companies, i.e., urban companies, since proximity allows them to more easily acquire information about borrowers' quality. Geographical distance between most banks and rural firms hinders the acquisition of "soft" information and possibly increases transaction costs 
associated with the frequent renegotiations of short-term debt. Therefore, if rural companies intend to raise debt capital, banks might be more likely to offer them longer-term debt.

Debt with longer maturity might increase the underinvestment problem as argued by Myers (1977). Long-term debt does not allow a firm to refinance before investment options expire therefore preventing the firm to re-price debt to avoid that gains from new projects accrue to debtholders. Rural firms might have sub-optimally less leverage than urban firms because without the ability to choose shorter-term debt they might carry less debt to limit underinvestment. In all, we conjecture that rural firms have longer-term debt and lower leverage than urban firms.

The monitoring hypothesis: If equity analysts and media outlets cover rural companies less effectively and frequently, banks and institutional bond investors might choose to monitor rural firms more frequently despite geographical remoteness to avoid moral hazard and asset substitution problems due to higher information asymmetry. In this case rural firms should carry shorter maturity debt but should not have significantly different leverage than urban firms because of a lack of underinvestment problems.

\section{Sample and data}

We obtain all financial accounting data about our sample firms from Compustat. As in Barclay and Smith (1995), we restrict our sample to industrial firms. We exclude financial firms because Compustat does not provide debt maturity data for them. Compustat reports the amount of long-term debt at fiscal year-end which is payable in more than one, two, three, four and five years. In constructing our debt maturity measures, we discard firm-year observations for which the total debt maturity is less than $0 \%$ or more than $100 \%$. 
We categorize our sample firms as urban and rural firms as in Loughran and Schultz (2005). From Compustat we obtain the county of the firm's headquarter. We then retrieve the longitude and latitude for the headquarters' counties and compute the distance between the firm's headquarters and each of the top 49 U.S. metropolitan locations according to the 2000 census. Specifically, we calculate the distance from point $\mathrm{a}$ and $\mathrm{b}$ as arc length as in Coval and Moskowitz (1999):

$\mathrm{d}_{\mathrm{ab}}=\operatorname{arcos}(\mathrm{deg}) \times 2 \pi \mathrm{r} / 360,(1)$

$\operatorname{deg}=\cos \left(l_{a} a_{a}\right) * \cos \left(\operatorname{lon}_{\mathrm{a}}\right) * \cos \left(\operatorname{lat}_{\mathrm{b}}\right) * \cos \left(\operatorname{lon}_{\mathrm{b}}\right)+\cos \left(\operatorname{lat}_{\mathrm{a}}\right) * \sin \left(\operatorname{lon}_{\mathrm{a}}\right) * \cos \left(\operatorname{lat}_{\mathrm{b}}\right) * \sin \left(\operatorname{lon}_{\mathrm{b}}\right)+\sin \left(\operatorname{lat}_{\mathrm{a}}\right) * \sin \left(\operatorname{lat}_{\mathrm{b}}\right),(2)$

where lat and lon are latitudes and longitudes, and $\mathrm{r}$ is the radius of the earth $(6,378$ kilometers).

We use headquarter location instead of state of incorporation because firms incorporate in a state with favorable taxes and corporate laws, independently from where the majority of its operations take place. We define as rural firms those companies that are no closer than 100 miles from any of those 49 locations. We define as urban firms those companies that are closer than 100 miles to any of the 10 most populated locations. We define the firms in between our rural and urban categorizations as small city firms as in Loughran (2008). The sample used for the leverage and debt maturity analysis consists of 53,260 firm-year observations and 9,134 unique firms between 1996 and $2005 .^{2}$

We then gather information about debt issues from Security Data Corporation (SDC) Global Issues (Thomson - One Banker). We form the initial sample by considering all U.S. nonfinancial firms that issue long-term debt (i.e., maturity longer than one year) between 1996 and

2 Our sample encompasses the pre- and post-Sarbanes Oxley periods which should bias the results against finding significant differences between urban and rural firms. Indeed, the enactment of the data and audit requirements of Sarbanes Oxley creates a more consistent flow of "hard" information and more importantly, since this reporting is now mandated by law, is a sunk cost in the framework of equity and debt issuances. See also Francis et al. (2007). 
2005 as reported by SDC-Global Issues. We consider all types of non-convertible corporate debt listed by SDC: public bonds, private 144A bonds, traditional private placements to sophisticated and accredited investors, and bank loans. ${ }^{3}$ Because some of the issuers reported by SDC-Global Issues are subsidiaries of publicly traded corporations, we assign the debt of subsidiaries to the parent company.

Because many firms place debt securities with the same characteristics within a limited period (see Denis and Mihov (2003) for a description of this issue), we aggregate similar issues by a firm within each quarter as in Arena and Howe (2009). In other related studies Gomes and Phillips (2007) aggregate debt issues by type within each month and Denis and Mihov (2003) aggregate within each year. Aggregating every three months allow us to reduce statistical dependency without significantly losing statistical power. The principal of the aggregated debt is the sum of the principals of the single debt issues, while the maturity of the aggregated debt is the weighted average of the maturities of the single issues.

We then match the SDC observations with our original Compustat sample eliminating the firms that either dataset does not cover. The final sample we use in the debt cost analysis consists of 13,839 issues by 3,153 firms, 1,699 urban, 1,175 small city, and 279 rural firms. The Appendix describes all the variables and their sources.

Our sample is geographically dispersed since we define at least one firm as rural in every state (to the exception of the District of Columbia) though there are important variations. Excluding Alaska, Hawaii and Puerto Rico firms, the sample firm that is the most distant from a Top 49 metropolitan area is Georesources, headquartered in Williams County, North Dakota,

3 Consistent with the literature (i.e., Fenn (2000), Arena and Howe (2009)), we call private placements of debt securities conducted pursuant to Section 4(2) of the 1933 Securities Act or to Rule 506 of regulation D as traditional private placements to distinguish them from 144A private bonds. 
866 miles from Minneapolis, the $16^{\text {th }}$ largest city in the country. Montana firms are on average 800 miles from either Denver or Seattle, respectively the $22^{\text {nd }}$ and $15^{\text {th }}$ largest metropolitan areas. On average, rural firms (excluding those in $\mathrm{HI}, \mathrm{AK}$, and PR) are 222 miles away from the closest large urban center.

Figure 1 presents the geographical dispersion of our sample. The map of Figure 1 serves two purposes. First, it identifies which counties of the United States we consider to be urban, small-city and rural as per our definition, which follows Loughran and Schultz (2005) criteria. The map reflects the population distribution in the country with a large percentage of the population on both coasts and upper Midwest and a still sparsely populated far west.

Second, Figure 1 overlays a darker shade to identify and locate, within each area, those counties in which the debt issuing firms in our sample reside. This is particularly informative for the rural firms as the majority of counties in the United States are rural. The map shows that few rural firms in our sample come from the mountain states and that many come from the Midwest, the South and the Northeast. In contrast, most of the urban counties are home to at least one debt issuing firm in our sample. The distribution of the small-city firms more closely parallels that of urban firms. Small-city firms tend to be located very near the center of the small city area, that is, the counties in the outer perimeter of our 100 miles zone tend not to have companies located there, a reflection of the importance of proximity.

\section{Descriptive and univariate statistics}

In this section we report univariate sample statistics related to the corporate debt decision and urban proximity. First, we look at the time-series distribution of the debt issues in our sample and then we turn to firm and deal characteristics. 
Table 1 presents time-series and deal type information about the debt issues that form our sample. The sample of this study covers 7,560 debt issues for urban firms, 4,941 debt issues by small city firms, and 1,338 debt issues for rural firms. Urban firms in our sample close the fewest debt deals in 1996 (625) and close the most in 1997 (908). Rural firms close the fewest debt deals in 1996 (94) and close the most in 1998 (164). Urban firms' choice of debt is 17\% public bonds, $64 \%$ bank loans, 13\% 144A debt, and 5\% non-bank traditional private placements. Comparatively, $20 \%$ of the rural firms' debt issues are public bonds, $63 \%$ are bank loans, $11 \%$ are $144 \mathrm{~A}$ bonds, and $6 \%$ are non-bank traditional private debt placements.

Panel A of Table 2 presents the characteristics of urban, small city, and rural firms for the entire Compustat sample. ${ }^{4}$ Rural firms are significantly smaller than urban firms as shown by Total Assets, Market Capitalization and Sales. We note that rural firms tend to have a higher percentage of Fixed Assets as part of their asset structure than urban firms. Capital Expenditures of rural firms as a percent of Total Assets are also significantly higher than for urban firms. In an unreported analysis we check if urban and rural firms concentrate in different industries but we do not find any industry clustering or any significant distributional difference. Nevertheless, in all our multivariate tests we include Industry Dummies to control for any potential industry effect, in addition to our size control variable.

Panel A also suggests that in general rural firms have better credit quality as 1) they are significantly less likely to post a loss as evidenced by the Loss Dummy, 2) when profitable, their Operating Return on Assets is significantly larger than that of urban firms, 3) they have significantly higher Interest Coverage Ratio, and 4) they are more likely to have an Altman's Z larger than 1.8. Despite this evidence, the mean credit rating of rural firms is not significantly

4 The tenor of the statistics presented in Panel A of Table 2 does not change if we narrow the focus to the firms for which we have debt issue information. We prefer to present results on the large sample to show that the results are not driven by any selection bias. 
different from the credit rating of urban firms (both are between $\mathrm{BB}+$ and $\mathrm{BBB}-$ ) and the median is only marginally significant. There are two potential explanations. First, since only about one quarter of Compustat firms have credit rating data, it is possible that the lack of significance is due to the significantly smaller sample. Second, even though profitability, interest coverage and default measures seem to indicate that rural firms have better credit quality, leverage is significantly higher for rural firms. Rural firms' mean leverage is $28 \%$ while urban firms' mean leverage is $25 \%$. These numbers are congruent with those of prior studies confirming the relation between leverage and corporate location evidenced by the literature. Loughran (2008) studying the 1980 - 2002 time period reports leverage of $28.5 \%$ for rural firms and $23.5 \%$ for urban firms. Similarly, Francis et al. (2007) report that, over the 1990 - 2004 period, leverage for rural firms is $29.3 \%$ and $23.1 \%$ for urban firms. Yet, the endogenous relation between leverage and debt maturity might partially explain the leverage differences between urban and rural firms. We investigate this issue in the following section of this study.

In the last row of Panel $\mathrm{A}$, we start exploring the difference in debt maturity between the urban and rural sub-samples by reporting the mean and median percentages of debt maturing in more than three years. We observe that rural firms hold longer term debt. Specifically, the difference of the mean (median) between the percentage of debt maturing in more than three years between rural and urban firms is $2.13 \%(2.39 \%)$ and statistically significant with t-statistic $=2.97(\mathrm{z}$-statistics $=2.48)$.

Overall, Panel A of Table 2 show that many firm characteristics are significantly different between rural and urban firms consistent with previous finance studies on location. In our multivariate analysis we control for an exhaustive set of firm characteristics to verify that 
corporate debt decisions are not purely driven by typical firm characteristics and that location has an incremental effect on these choices over other firm characteristics.

Table 2 - Panel B explores the univariate differences in the deal characteristics in our sample. Reflecting the difference in firm size from Panel A, rural firms raises less capital on a per deal basis on average, $\$ 414$ million to the $\$ 492$ million for urban firms. Due to urban firms being larger (as shown in Panel A), the debt principal/assets ratio is not significantly different between urban, small city, and rural firms. Rural firms' debt is characterized by higher spread than urban firms (on average 160 basis points versus 147 basis points) as well as by longer maturity. Similarly, urban firms are more likely to be underwritten by a prestigious bank (72\% versus $69 \%$ ) and benefit from larger syndicate to market their deal (3.7 versus 3.2 managers on average). Interestingly, the gross spread, i.e., the percentage compensation for the underwriters is larger for urban firms than it is for rural firms even if the difference is not significant. The difference is possibly a reflection of the lower likelihood that rural firms are underwritten by prestigious banks which might charge higher spreads on average. For the subset of our sample that consists of bank loans, we also show that rural firms are more likely to borrow from nonurban banks and that are more likely to repeatedly borrow from the same bank (as measured by Loan Intensity, the number of loans that a specific bank grants to the borrower in the last 3 years). The results of these two variables provide preliminary evidence that rural banks rely more on relationship banking than urban firms. Overall, the results of Table 2 are indicative that our proximity hypothesis dominates the monitoring hypothesis; however, the evidence is not conclusive due to the lack of controls in this setting. 


\section{Multivariate analysis}

\subsection{Cost of debt}

We begin our multivariate analysis by investigating the imposition of higher borrowing cost to rural firms in terms of wider yield spreads. We investigate how firm's location affects debt yields by analyzing new issue yields as Crabbe and Turner (1995) instead of relying on secondary market data. Secondary market data on yields has the benefit of directly reflecting liquidity implications. However, as argued by Crabbe and Turner (1995), liquidity effects are also observable in the primary market because bond issues carry an illiquidity premium to cover transaction costs assuming a nonzero probability that primary investors will sell the security in the secondary market (Amihud and Mendelson (1986)).

We test the relation between firm location and the cost of debt financing by means of four different regression specifications (without and with year and industry fixed effects) in which we control for firm and debt characteristics that are related to the cost of debt. As in Klock et al. (2005) and Chava et al. (2009), we correct the standard errors for heteroskedasticity and clustering at the firm level.

The dependent variable is the debt yield spread, the number of percentage points over the U.S. Treasury security of similar maturity. We include three dummy variables that are designed to control for the type of debt issued by the firms and to distinguish them from public debt issuances: Loan, 144A, and Private to represent bank loans, 144A, and traditional private placement issues. We would expect that bank loans are less expensive than public debt because of more intensive and direct monitoring. We also expect that private placement (above all 144A) are more expensive than the other two alternatives because they usual lack covenants and contractual obligations present in public debt and bank loans (Fenn (2000)). We use the 
logarithm of total assets of the firm (Lnassets) to control for firm size. We consider Leverage to control for credit risk and probability of default. We control for the effects of profitability and asset stability on the cost of debt with returns on assets (Profitability) and the proportion of tangible assets to total assets (Fixed Assets). The model also includes three debt-specific variables that apply to both public and bank debt: the logarithm of the issue size (Lnprincipal), the logarithm of debt maturity (Lnmaturity) and the number of banks that form the debt issue syndicate (All Managers). Call Dummy (an indicator equal to 1 when the bonds are callable), Junior Dummy (an indicator equal to 1 when the bond is subordinated) are public-debt-specific variables. Term Loan Dummy (an indicator equal to 1 with the loan is a term loan, and 0 when the loan is a revolver) is a loan-specific variable. We also include our measure of Bank Reputation related to the underwriters. Deals underwritten by the largest investment and commercial banks generally lead to lower spreads. We would then expect the Bank Reputation dummy to be negative. Finally, we control for the term spread (the difference between 10-year and 2-year CMT Treasury yield) and credit spread (the difference between BAA and AAA bond yields) in the month of the issue.

Additionally, we account explicitly for firms' credit ratings. We recognize that, as shown by Kaplan and Urwitz (1979) and Ziebart and Reiter (1992), credit ratings are related to several firm characteristics that are also important determinants of the corporate decision on the type of debt to be issued. Therefore regressing credit ratings along with other firm characteristics would generate multicollinearity and erroneously affect the significance of the regression coefficients. To avoid multicollinearity we implement a two-step procedure as in Johnson (1997) and Arena (2011). In the unreported first step we regress issuer credit ratings on firm characteristics that have been found to be related to ratings (Lnassets, leverage, interest coverage, loss dummy, fixed 
assets) along with the rural dummy. The residual variable obtained this way is highly correlated with the issuer credit rating variable, but is orthogonal to the other explanatory variables. In the second step (presented in Table 3) we estimate fixed effects regression with yield spread as dependent variable and the residuals of the first regression (Rating Residuals) and all the other firm and issue characteristics as independent variables. The orthogonality between the rating residual variable and the other independent variables assures a correct estimation of the coefficients.

To avoid dropping observations with missing ratings we apply a method often used to avoid losing observations with missing Compustat variables (e.g., Palia (2001) and Fama (1985)). The method consists of setting the missing ratings to zero and introducing an indicator variable (Rating Missing Dummy) that is set to unity for the missing observations. The variable Rating Missing Dummy also controls for the firm's access to public markets as in Faulkender and Petersen (2006) and quantify if information is available about the firm as in Lee and Mullineaux (2004).

Table 3 presents our regression results. First and foremost, across all specifications, we show that rural firms face higher borrowing costs than urban firms ceteris paribus, validating our proximity hypothesis. In specification (4) which accounts for year and industry effects, we show that rural firms on average face a significantly higher spread between 8 and 9 basis points. This difference in spread translates to an economic significant present value of additional annual interest expenses of about $\$ 70$ million for the average rural firm in our sample. Rural firms have a cost disadvantage in the credit markets.

The signs of coefficients of the control variables are consistent with the literature. Specifically, firm size, asset tangibility and profitability are negatively related to yield spreads. 
Credit risk, of which Leverage and the Subordinate Dummy are proxies, is positively related to spreads. Consistent with this result, the Rating Residuals variable is significant at the $1 \%$ level and negatively related to yield spreads. Subordinated and callable bonds are characterized by higher yields. Term loans are characterized by higher spreads than revolving facilities, consistent with Chava et al. (2009). The term spread and credit spread are also related to bond yield spread. We see that maturity reduces the yield spread. This result is consistent with prior studies of the term structure of credit spreads (see Sarig and Warga (1989), Fons (1994) and Kealhofer (2003)), particularly for speculative grades. Lastly, we note that deals not underwritten by top investment banks are more expensive by about 21 basis points.

\subsection{Debt syndicate composition}

\subsubsection{Syndicate size}

We test the effect of firm location on the size of the lending and underwriting syndicates with Poisson regressions in which the dependent variable is the number of banks in the syndicate. Table 4 presents the results of these regressions. In the first specification we control for type of debt, firm size and profitability and issue characteristics. In the second specification we also include an indicator variable that measures credit quality (Investment Grade, an indicator equal to 1 when the firm is rated investment grade). Flannery (1986) proposes that low quality firms cannot borrow short-term because of the high cost of monitoring and therefore self-select into longer maturity. We control for credit quality in our specification to avoid the confounding influence of the quality issue. To avoid dropping observations we include the Rating Missing Dummy as in Table 3. 
In the third specification we also introduce other firm characteristics related to credit quality and credit rating residuals by implementing the same two-step procedure used in Table 3. In all three specifications the rural indicator variable is negative and significant. This result shows that bank syndicates that underwrite debt for rural firms are smaller than for urban firms, ceteris paribus. This result is robust to the inclusion to firm characteristics, debt type, issue characteristics, bank reputation, and credit quality of the issuers.

In addition to the main result concerning the effect of proximity on syndicate size, we also find that private debt (banks loans, 144A debt, and traditional private placements) are likely to be syndicated by fewer banks. This result is consistent with contractual differences between public bonds and private debt, in particular bank loans. Private borrowers have concerns about the identity of the banks in the syndicate because each syndicate member has complete contractual rights and responsibilities and is involved in any possible subsequent loan restructuring. The lead bank has also to carefully select the syndicate participants because they can influence resale activities. Unlike a lead underwriter of public bonds, which distributes securities to public investors, loan syndicate and traditional private placement arrangers often require consent for subsequent sales or establish minimum size requirements for future resales (Lee and Mullineaux (2004)).

The other results related to our control variables are consistent with Lee and Mullineaux (2004). Firms for which less information is available (firms with missing rating) attract smaller syndicates. Syndicate size significantly declines with credit risk as shown by the Investment Grade, Rating Residuals, Loss and Leverage coefficients as smaller and more concentrated syndicates form when credit risk is high in order to enhance monitoring incentives. More reputable banks (measured by Bank Reputation), which have access to a larger network of 
financial institutions, form larger syndicates. Moreover, larger syndicates underwrite larger, longer maturity debt, and are more likely to underwrite subordinated and callable debt.

\subsubsection{Reputation of banks in the syndicate}

We test the relation between firm location and the reputation of the underwriting and lending banks by means of probit regressions in which the dependent variable is a binary variable equal to 1 if a reputable bank is the lead underwriter of an issue, and 0 otherwise. For debt issues with multiple lead underwriters, the dependent variable equals 1 if at least one of the co-lead banks is a reputable bank. Similar to Fang (2005) we define as reputable banks the top 8 investment and commercial banks for dollar amount underwritten in the US for bonds and syndicated loans during our sample period ${ }^{5}$. We present the results in Table 5. Similar to Table 4 we present three specifications. The first column of the table presents a regression with debt type indicators, firm characteristics, and issue characteristics and excludes credit rating variables. The second column includes the Investment Grade variable and the Rating Missing Dummy. The third column presents the results of a regression in which we include other firm characteristics related to credit quality in addition to the Rating Residuals variable that we obtain with the same method we apply in the third regression specification of Table 4 .

In all specifications, the rural indicator variable is negative and significant. Everything else constant, the most prestigious banks, which are located in large urban areas, are less likely to underwrite debt and lend to rural companies. The coefficients of our control variables provide interesting results that both complement and confirm Fang (2005). We show that more reputable banks are more likely to take a leadership role in public debt transactions than they are in private

${ }^{5}$ Our data is consistent with Fang's (2005) as seven of our Top 8 bond underwriters match. Our overall Top 8 does differ as we include commercial banks in their role as loan providers. 
debt transactions (i.e., loans, 144A bonds, and traditional private placements). Larger firms, firms that issue larger amount of debt, and firms with better credit quality attract more reputable underwriters. Reputable banks are less likely to underwrite debt for firms that do not have access to public debt markets, as proxied by the Rating Missing Dummy as in Faulkender and Petersen (2006).

\subsection{Relationship banking}

We investigate if rural firms are more likely to rely on relationship banking by performing a multivariate analysis on the subsample consisting of bank loans. We test the effect of firm location on relationship banking in two ways. Our first test consists of Poisson regressions in which the dependent variable is Loan Intensity. Similar to the Ivashina et al. (2009) Loan Intensity $(N)$ variable, Loan Intensity consists of the number of loans that a specific bank grants to the borrower in the last 3 years. For syndicated loans, we consider all bookrunners and agents. Our second test consists of Probit regressions in which the dependent variable is the Non_Urban Bank indicator variable, an indicator equal to 1 when the lender (the lead lending bank for syndicated loans) is headquartered in a non-urban area (rural or small city area), and 0 otherwise.

Panel A of Table 6 presents the results of the Loan Intensity Poisson regressions. Similar to Table 5 we present three specifications. The first column of the table presents a regression with firm characteristics and issue characteristics. The second column includes the Investment Grade variable and the Rating Missing Dummy. The third column presents the results of a regression in which we include other firm characteristics related to credit quality in addition to the Rating Residuals variable. We include credit quality variables in the regressions because, as 
mentioned by Ivashina et al. (2009), firms at higher credit risk may be more likely to benefit from the enhanced monitoring that relationship banking provides.

In all specifications, the rural indicator variable is positive and significant at the $1 \%$ level. Everything else constant, rural banks are more likely to rely on relationship banking than urban firms. This result provides evidence that rural firms are likely to overcome their informational disadvantage through relationship banking and by repeatedly borrowing from their relationship banks. In addition to location, also firm size, loan maturity, and firm credit quality affect the incidence of relationship banking. Firms that rely on relationship banking issue shorter-term loans. This result suggests that in relationship banking lenders increase monitoring by offering shorter loans. Moreover, the investment-grade variable and the other variables related to credit risk (e.g., leverage, loss dummy, interest coverage) show that companies at higher credit risk are more likely to rely and benefit from the monitoring provided by relationship banking as suggested by Ivashina et al. (2009).

Panel B of Table 6 presents the results of the Non-Urban Bank Probit regressions. The dependent variable of these regressions is a Non-Urban Bank indicator rather than just a rural bank indicator because rural banks originate only about $1 \%$ of the loans in our sample. Dividing the banks into urban and non-urban (banks headquartered in one of the 10 most populated U.S. cities vs. banks headquartered anywhere else in the U.S.) allows us to investigate relationship banking from a location standpoint while maintaining statistical power. The main independent variable is a Non-urban indicator (an indicator variable equal to 1 when the borrowing firm is headquartered in a non-urban area) to be econometrically consistent with the dependent variable and effectively test for location-based relationship banking. In all specifications, the non-urban indicator variable is positive and significant at the $1 \%$ level. Everything else constant, non-urban 
firms are more likely to create banking relationships with non-urban banks. This result provides evidence that firms outside large city areas are likely to overcome their informational disadvantage through relationship banking with proximate banks. The coefficients of the control variables show that firms borrowing from non-urban banks are significantly smaller and borrow significantly less. Overall, the two panels of Table 6 provide evidence supporting the reliance of relationship banking by firms located in rural and small city areas.

\section{Additional tests and robustness checks}

In this section we provide the results from a series of additional tests. Specifically, we investigate if firm location affects debt maturity, leverage, and the corporate choice between private and public debt. We also test if our results on cost of debt hold when controlling for actual distance.

\subsection{Leverage and debt maturity}

We analyze the effect of firm's location on debt maturity and leverage in a multivariate setting in Table 7. Because of the endogenous relation between leverage and debt maturity documented by Barclay et al. (2003), we model a system of two simultaneous equations which recognizes the endogenous determination of leverage and maturity. Table 7 shows the results of the second stage regression results for leverage and debt maturity. ${ }^{6}$ As in Barclay and Smith (1995) we use the percentage of debt maturing after 3 years as the debt maturity variable.

The specification of the leverage regression reported in Table 7 - Panel A shows the positive relation between debt maturity and leverage well established by the debt maturity

\footnotetext{
${ }^{6}$ The unreported results of the first-stage regressions that we use to generate the estimated values of leverage and debt maturity are available upon request.
} 
literature. The Rural Dummy and Small City Dummy coefficients are marginally significant in the first specification but lose their significance when controlling for year and industry effects. This result shows that there is no difference in Leverage across our two sub-samples when controlling for other firm characteristics, fixed effects, and the endogenous relation between leverage and debt maturity. By thoroughly controlling for possible determinants of leverage, and recognizing the endogeneity between leverage and debt maturity, the seeming difference in leverage between our two groups disappears. Rural firms exhibit similar leverage to urban firms.

As mentioned earlier, our leverage regression includes explanatory variables which previous leverage and maturity studies (e.g., Barclay and Smith (1995), Johnson (2003)) show to be related to leverage. The coefficients of the control variables of the leverage equation are generally consistent with previous capital structure studies. Consistent with Myers and Majluf (1984), firm size (Lnassets) is significant and negatively related to leverage. Profitability is significant and negatively related to leverage consistent with Myers (1984) pecking order. Consistent with Harris and Raviv (1990) and Williamson (1988), fixed assets are positive and significantly related to leverage. Consistent with DeAngelo and Masulis (1980), company with more investment tax credits (ITC) have lower leverage. Finally, our regulated indicator variable is positive and significant consistent with Smith (1986) who argues that regulated firms have lower debt agency costs and higher leverage.

We investigate the effect of firm location on debt maturity in Panel B if Table 7. To properly identify the system of equations, as in Datta et al. (2005) we exclude from the debt maturity regressions profitability, fixed assets, and the NOL and ITC indicators. The results show that rural firms do not carry significantly longer maturity debt. However small city firms 
carry longer term debt. This result persists when we control for year and industry fixed effects, the small city dummy is also significant.

Consistent with Smith and Watts (1992) and Barclay and Smith (1995) we find a positive and significant relation between leverage and debt maturity. Firm size (Lnassets) is positive and significant consistent with Diamond (1991). Asset maturity is also significantly related to debt maturity. The abnormal earnings variable is negative and significant consistent with Flannery (1986) and Diamond (1991). Consistent with Myers (1977) who argues that firms use shorter maturity debt to minimize the underinvestment problem, $\mathrm{M} / \mathrm{B}$ and negative and significantly related to debt maturity. Consistent with Barclay and Smith (1995), regulated firms have longer maturity debt than unregulated firms.

In untabulated robustness checks, we replicate the univariate analysis of Table 2 and the multivariate analysis of Table 7 by limiting our sample to the firms for which we have SDC debt issue data, the same sample we use for the other tests presented in this paper. The debt maturity distributions for rural and urban firms remain significantly different for all five years when we use this sample. Moreover, the significant difference in debt maturity between small city and urban firms evidenced in Table 7 persists when we perform the two-stage regressions with this smaller sample. The sign and significance of all the other explanatory variables are also comparable to those presented in Table 7.

\subsection{Does firm location affect the choice between private and public debt}

It is possible that firms more distant from urban centers might rely on more private debt to attenuate information asymmetry issues. In an untabulated test, we investigate with a logistic regression if firm location influences the type of debt that firms issue. We use a similar approach 
to Denis and Mihov (2003), Arena and Howe (2009) and other studies on the corporate choice between private and public debt. The dependent indicator variable is 0 when the debt instrument issued is a public bond and 1 when the debt instrument is private (bank loan or non-bank private debt). In addition to the rural indicator variables we control for a thorough set of variables that the literature has found related to the debt choice. The rural indicator variable is not significant. We therefore do not find evidence of an effect of location on the corporate choice between private and public debt after controlling for other firm characteristics related to credit quality (leverage, profitability, credit ratings, etc.). The coefficient and significance of the other variables are consistent with prior evidence.

\subsection{Cost of debt controlling for raw distance from the closest urban area}

In the multivariate analyses presented in the previous sections of this study, our main location variable is an indicator variable that distinguishes between rural and urban firms. While we believe that this measure, which is consistent with previous studies on the effect of geographical location on financial decisions, is the best proxy of distance from urban areas, it is important to verify that our results persists when using an alternative proxy of firm location. As

an alternative, we replicate our debt yield regressions using the distance in thousands of kilometers (621 miles) between the firm's headquarters and the center of its closest urban area (Distance). As described section 3, our urban areas are the ten most populated U.S. cities according to the 2000 census.

Table 8 presents the results of these yield spread regressions. The distance variable is positive and significant at the $5 \%$ level while the small city dummy is negative and significant at the 5\% level. The results suggest that firms that are farther away from large financial centers pay 
higher interest but the proximity with a small city (city ranked 11 to 49 by population according to the 2000 census) reduces this disadvantage. The results are also economically significant. The coefficients of column (4) imply that a firm that is 621 miles $(1,000 \mathrm{~km})$ from the closest large city, ceteris paribus, pays an interest that is 14 basis points $(0.1400 * 100)$ higher than a company located in a large city. However, if the firm is in the proximity of a small city, then the interest difference from an urban firm decreases to 6.82 basis points $\left[(0.1400-0.0718)^{*} 100\right]$. The sign and significance of the coefficients of all the control variables are consistent with those presented in Table $3 .^{7}$

\section{Conclusion}

Although several studies provide extensive evidence on the effect of corporate location on equity investments (e.g., Coval and Moskowitz (1999), Grinblatt and Keloharju (2001), Loughran and Schultz (2005), Malloy (2005), and Loughran (2008)), the finance literature lacks a full examination of the relation between corporate location and the firm's debt characteristics. In this study we complement the evidence offered by the literature on the relation between firm location and corporate decisions by analyzing the effect of proximity to urban areas on debt syndicate composition, corporate debt policy, and debt costs.

Distance from urban areas where a majority of banks and other institutional debt investors are located put rural firms at an informational disadvantage when issuing debt. We show that this informational disadvantage has important implication for the cost of debt, debt underwriting and corporate debt structures. Specifically, we find that rural firms face higher spreads than comparable urban firms. Rural firms on average pay an additional 9 basis points

7 In untabulated tests, we replicate all other multivariate analyses using the raw distance variable instead of the rural indicator. The results are comparable. 
over their urban counterparts solely based on the location of their headquarters. We also document that rural firms have limited access to better intermediation in the market for corporate debt because prestigious underwriters are less likely to bring rural firms' debt to market. We also find that smaller syndicates underwrite debt and lend to rural firms. Therefore, rural firms surrender some degree of financial flexibility over their urban counterparts and pay more in interest. Rural firms and small city firms are more likely to rely on relationship banking with non-urban banks for their borrowing needs in an attempt to reduce the negative effect of their location. Additionally, we document that small city firms' debt maturity is longer than that of urban firms after accounting for documented debt maturity structure determinants and for the endogenous relation between debt maturity and leverage. A firm's location, however, does not appear to have an effect on firm's leverage.

Our results on the effect of firm location on corporate debt yields, debt underwriting, and relationship banking are robust to a thorough set of control variables which consists of several firm characteristics, corporate performance measures as well as debt characteristics. Overall our paper presents strong evidence that proximity to urban areas where financial centers are concentrated has a significant influence on the corporate debt decision making process. 


\section{References}

Amihud, Y., Mendelson, H., 1986. Asset pricing and the bid-ask spread. Journal of Financial Economics 17, 223-249.

Arena, M.P., 2011. The corporate choice between public debt, bank loans, traditional private debt placements, and 144A debt issues. Review of Quantitative Finance and Accounting $36,391-416$.

Arena, M.P., Howe, J.S., 2009. Takeover exposure, agency, and the choice between private and public debt Journal of Financial Research 32, 199-230.

Barclay, M., Marx, L., Smith, C.W.J., 2003. The joint determination of leverage and maturity. Journal of Corporate Finance 9, 149-167.

Barclay, M.J., Smith, C.W.J., 1995. The maturity structure of corporate debt. Journal of Finance 50, 609-632.

Bebchuk, L.A., Cohen, A., 2003. Firms' decisions where to incorporate. Journal of Law and Economics 46, 383-425.

Becker, B., 2007. Geographical segmentation of US capital markets. Journal of Financial Economics 85, 151-178.

Berger, A.N., Miller, N., Petersen, M.A., Rajan, R., Stein, J., 2005. Does function follow organizational form? Evidence from the lending practices of large and small banks. Journal of Financial Economics 76, 237-269.

Brickley, J.A., Linck, J.S., Smith, C.W.J., 2003. Boundaries of the firm: Evidence from the baning industry. Journal of Financial Economics 70, 351-383.

Butler, A.W., 2008. Distance still matters: Evidence from municipal bond underwriting. Review of Financial Studies 21, 763-784.

Chava, S., Livdan, D., Purnanandam, A., 2009. Do shareholder rights affect the cost of bank loans? Review of Financial Studies 22, 2973-3004.

Coval, J.D., Moskowitz, T.J., 1999. Home bias at home: Local equity preference in domestic portfolios. Journal of Finance 54, 2045-2073.

Crabbe, L.E., Turner, C.M., 1995. Does the liquidity of a debt issue increase with its size? Evidence from the corporate bond and medium-term note markets. Journal of Finance 50, $1719-1734$.

Dass, N., Massa, M., 2011. The impact of a strong bank-firm relationship on the borrowing firm. Review of Financial Studies 24, 1204-1260. 
Datta, S., Iskandar-Datta, M., Raman, K., 2005. Managerial stock ownership and the maturity structure of corporate debt. Journal of Finance 60, 2333-2350.

DeAngelo, H., Masulis, R.W., 1980. Optimal capital structure under corporate and personal taxation. Journal of Financial Economics 8, 3-30.

Denis, D.J., Mihov, V.T., 2003. The choice among bank debt, non-bank private debt and public debt: evidence from new corporate borrowings. Journal of Financial Economics 70, 3-28.

Diamond, D.W., 1991. Monitoring and reputation: The choice between bank loans and directly placed debt. Journal of Political Economy 99, 689-721.

Fama, E.F., 1985. What's different about banks. Journal of Monetary Economics 15, 29-39.

Fang, L.H., 2005. Investment bank reputation and the price and quality of underwriting services. Journal of Finance 60, 2729-2761.

Faulkender, M., Petersen, M.A., 2006. Does the source of capital affect capital structure? Review of Financial Studies 19, 45-79.

Fenn, G.W., 2000. Speed of issuance and the adequacy of disclosure in the 144A high-yield debt market. Journal of Financial Economics 56, 383-405.

Flannery, M.J., 1986. Asymmetric information and risky debt maturity choice. Journal of Finance 41, 18-38.

Fons, J.S., 1994. Using default rates to model the term structure of credit risk. Financial Analysts Journal, 25-32.

Gomes, A., Phillips, G., 2007. Why do public firms issue private and public securities? Working Paper, Washington University.

Grinblatt, M., Keloharju, M., 2001. How distance, language, and culture influence stockholdings and trades. Journal of Finance 56, 1053-1073.

Harris, M., Raviv, A., 1990. Capital structure and informational role of debt. Journal of Finance 45, 321-349.

Hauswald, R., Marquez, R., 2006. Competition and strategic information acquisition in credit markets. Review of Financial Studies 19, 967-1000.

Ivashina, V., Nair, V.B., Saunders, A., Massoud, N., Stover, R., 2009. Bank debt and corporate governance. Review of Financial Studies 22, 41-77.

Johnson, S., 2003. Debt maturity and the effects of growth opportunities and liquidity risk on leverage. Review of Financial Studies 16, 209-236.

Johnson, S.A., 1997. An empirical analysis of the determinants of corporate debt ownership structure. Journal of Financial and Quantitative Analysis 32, 47-69. 
Kaplan, R.S., Urwitz, G., 1979. Statistical models of bond ratings: A methodological inquiry. Journal of Business 52, 231-262.

Kealhofer, S., 2003. Quantifying credit risk II: Debt valuation. Financial Analysts Journal 59, 78-92.

Klock, M., Mansi, S., Maxwell, W., 2005. Does corporate governance matter to bondholders? Journal of Financial and Quantitative Analysis 40, 693-719.

Krugman, P.R., 1991. Increasing returns and economic geography. Journal of Political Economy 99, 483-499.

Lee, S.W., Mullineaux, D.J., 2004. Monitoring, financial distress, and the structure of commercial lending syndicates. Financial Management 33, 107-130.

Leland, H.E., Pyle, D.H., 1977. Informational asymmetries, financial structure, and financial intermediation. Journal of Finance 32, 371-387.

Loughran, T., 2008. The impact of firm location on equity issuance. Financial Management 37, $1-21$.

Loughran, T., Schultz, P., 2005. Liquidity: Urban versus rural firms. Journal of Financial Economics 78, 341-374.

Malloy, C.J., 2005. The geography of equity analysis. Journal of Finance 60, 719-755.

Myers, S.C., 1977. Determinants of corporate borrowing. Journal of Financial Economics 5, 147175.

Myers, S.C., 1984. The capital structure puzzle. Journal of Finance 39, 575-592.

Myers, S.C., Majluf, N., 1984. Corporate financing and investment decisions when firms have information that investors do not have. Journal of Financial Economics 13, 187-221.

Palia, D., 2001. The endogeneity of managerial compensation in firm valuation: a solution. Review of Financial Studies 14, 735-764.

Papke, L.E., 1991. Interstate business tax differentials and new firm location. Journal of Public Economics 45, 47-68.

Petersen, M.A., Rajan, R.G., 2002. Does distance still matter? The information revolution in small business lending. Journal of Finance 57, 2533-2570.

Sarig, O., Warga, A., 1989. Some empirical estimates of the risk structure of interest rates. Journal of Finance 57, 2533-2570.

Smith, C.W.J., 1986. Investment banking and the capital acquisition process. Journal of Financial Economics 15, 581-604. 
Smith, C.W.J., Watts, R., 1992. The investment opportunity set and corporate financing, dividend, and compensation policies. Journal of Financial Economics 32, 263-292.

Williamson, O.E., 1988. Corporate finance and corporate governance. Journal of Finance 43, 567-591.

Ziebart, D.A., Reiter, S.A., 1992. Bonds ratings, bond yields and financial information.

Contemporary Accounting Research 9, 252-282. 


\begin{tabular}{|c|c|c|}
\hline & $\begin{array}{c}\text { APPENDIX } \\
\text { Variable Definitions and Sources }\end{array}$ & \\
\hline Variable & Definition & Source \\
\hline $144 A$ & Indicator equal to 1 when the debt issue is a $144 \mathrm{~A}$ debt placement & SDC \\
\hline Abnormal Earnings & $\begin{array}{l}\text { (Earnings in year } \mathrm{t}+1-\text { earnings in year } \mathrm{t}) /(\text { share price } \times \\
\text { outstanding shares in year } \mathrm{t} \text { ). }\end{array}$ & Compustat \\
\hline Altman & $\begin{array}{l}\text { Indicator variable equal to one when Altman's (1977) } \mathrm{Z} \text { is smaller } \\
\text { than 1.81. Altman's } \mathrm{Z} \text { is calculated as } 1.2 \text { (Working Capital/Total } \\
\text { Assets) }+1.4 \text { (Retained Earnings/Total Assets) }+3.3 \text { (Earnings } \\
\text { Before Interest and Taxes/Total Assets) }+0.6 \text { (Market Value of } \\
\text { Equity/Book Value of Long-Term Debt) + (Net Sales/Total Assets) }\end{array}$ & Compustat \\
\hline Asset Maturity & $\begin{array}{l}\text { (Gross property, plant, and equipment /total assets }) \times(\text { gross } \\
\text { property, plant, and equipment/depreciation expense })+(\text { current } \\
\text { assets /total assets }) \times(\text { current assets /cost of goods sold })\end{array}$ & Compustat \\
\hline Assets & $\begin{array}{l}\text { Total assets of the firm expressed in millions of dollars calculated at } \\
\text { the end of the fiscal year preceding the private placement }\end{array}$ & Compustat \\
\hline Bank & Indicator equal to 1 when the debt issue is a bank loan & SDC \\
\hline Bank Reputation & $\begin{array}{l}\text { Indicator equal to } 1 \text { when the debt is underwritten or the loan is } \\
\text { provided by a syndicate containing at least one reputable bank (a } \\
\text { reputable bank is defined as one the top } 8 \text { investment and } \\
\text { commercial banks for dollar amount underwritten in US for bonds } \\
\text { and syndicate loans during our sample period). }\end{array}$ & SDC \\
\hline Bond Gross Spread & $\begin{array}{l}\text { Underwriting gross spread for the issue bond, expressed in } \\
\text { percentage }\end{array}$ & SDC \\
\hline Call Dummy & Indicator equal to 1 when the debt issue is callable & SDC \\
\hline Cap Exp / Tot. Assets & Capital expenditures divided by total assets & Compustat \\
\hline Credit Rating & $\begin{array}{l}\text { Numerical conversion of S\&P and Moody's issuer credit ratings as } \\
\text { in Klock et al. (2005). Larger numbers represent higher ratings } \\
\text { (e.g., AAA is } 22, \mathrm{AA}+\text { is } 21, \mathrm{BBB} \text { is } 14, \mathrm{C} \text { is } 2 \text {, and D is } 1 \text { ) }\end{array}$ & Compustat \\
\hline Credit Spread & Monthly difference between BAA and AAA bond yields & Fed H.15 \\
\hline Debt Maturity & The percentage of firm's debt maturing in more than three years & Compustat \\
\hline Distance & $\begin{array}{l}\text { Distance in thousands of Kms between the issuing firm and the } \\
\text { closest of the top } 10 \text { populated cities in the US }\end{array}$ & $\begin{array}{l}\text { Compustat } \\
\text { and Census }\end{array}$ \\
\hline Fixed Assets & $\begin{array}{l}\text { Fraction of fixed assets calculated as gross PPE divided by total } \\
\text { assets }\end{array}$ & Compustat \\
\hline Interest Cov Dummy & $\begin{array}{l}\text { Indicator equal to } 1 \text { when Interest coverage (calculated as earnings } \\
\text { before interest, taxes, amortization and depreciation divided by } \\
\text { interest expense) is larger than } 1.5\end{array}$ & Compustat \\
\hline Investment Grade & Indicator equal to 1 when the issuing firm is rated investment grade & $\begin{array}{l}\text { Compustat } \\
\text { and SDC }\end{array}$ \\
\hline ITC & Indicator equal to 1 for firms with investment tax credits & Compustat \\
\hline Junior Dummy & Indicator equal to 1 when the debt issue is subordinated & SDC \\
\hline Leverage & Total debt divided by total assets & Compustat \\
\hline Lnassets & Natural logarithm of Assets & Compustat \\
\hline Lnassets 2 & Natural logarithm of Assets squared & Compustat \\
\hline
\end{tabular}




\begin{tabular}{|c|c|c|}
\hline Lnprincipal & Natural logarithm of Principal & SDC \\
\hline Lnmaturity & Natural logarithm of Maturity & SDC \\
\hline Loan & Indicator variable equal to 1 when the debt is a bank loan & SDC \\
\hline Loan Intensity & $\begin{array}{l}\text { Number of loans originated to the borrower by a specific bank in } \\
\text { the last } 3 \text { years. For syndicated loans, all bookrunners and agents } \\
\text { are considered. }\end{array}$ & SDC \\
\hline Loss & $\begin{array}{l}\text { Indicator variable equal to one if the net income before } \\
\text { extraordinary item is negative, and zero otherwise }\end{array}$ & Compustat \\
\hline$M / B(Q)$ & $\begin{array}{l}\text { Ratio of the market value of equity minus the book value of equity } \\
\text { plus the book value of assets to the book value of assets }\end{array}$ & Compustat \\
\hline Marketcap & Market capitalization of the firm three months before the debt issue & CRSP \\
\hline Maturity & Years to final maturity of the debt issue & SDC \\
\hline NOL & Indicator equal to 1 for firms with operating loss carry-forwards & Compustat \\
\hline Non-urban & $\begin{array}{l}\text { Indicator equal to } 1 \text { when the firm is located in a rural or small city } \\
\text { area and } 0 \text { otherwise }\end{array}$ & $\begin{array}{l}\text { Compustat } \\
\text { and Census }\end{array}$ \\
\hline Non-urban Bank & $\begin{array}{l}\text { Indicator equal to } 1 \text { when the lender (for a single-bank loans) or the } \\
\text { lead bank of the syndicate (the agent for syndicated loans) is a non- } \\
\text { urban bank }\end{array}$ & $\begin{array}{l}\text { SDC and } \\
\text { Census }\end{array}$ \\
\hline Principal & Size of the debt offering expressed in millions of dollars & SDC \\
\hline Profitability & Net income before extraordinary items divided by total assets & Compustat \\
\hline Public & Indicator equal to 1 when the debt issue is a public bond & SDC \\
\hline Rating Dummy & $\begin{array}{l}\text { Indicator variable equal to one when the firm is rated by S\&P or } \\
\text { Moody's, and zero otherwise }\end{array}$ & $\begin{array}{l}\text { Compustat } \\
\text { and SDC }\end{array}$ \\
\hline Rating Missing Dummy & $\begin{array}{l}\text { Indicator variable equal to one when the firm is not rated by S\&P or } \\
\text { Moody's, and zero otherwise }\end{array}$ & $\begin{array}{l}\text { Compustat } \\
\text { and SDC }\end{array}$ \\
\hline Rating Residual & See Table VIII and Table IX headers & Compustat \\
\hline Regulated Dummy & Indicator equal to 1 for regulated firms and 0 otherwise. & Compustat \\
\hline Rural & $\begin{array}{l}\text { Indicator equal to } 1 \text { when the firm is located in a rural area (at least } \\
100 \text { miles from the center of any metropolitan area of } 1,000,000 \text { or } \\
\text { more people according to the } 2000 \text { Census) and } 0 \text { otherwise }\end{array}$ & $\begin{array}{l}\text { Compustat } \\
\text { and } 2000 \\
\text { Census }\end{array}$ \\
\hline Sales & Firm's revenues in million of dollars & Compustat \\
\hline Small City & $\begin{array}{l}\text { Indicator equal to } 1 \text { when the firm is not defined as rural and is not } \\
\text { in an urban area (not in one of the } 10 \text { largest metropolitan areas } \\
\text { according to the } 2000 \text { Census), and } 0 \text { otherwise }\end{array}$ & \\
\hline Spread & $\begin{array}{l}\text { Debt yield spread as the number of basis points over the Treasury } \\
\text { security of similar maturity }\end{array}$ & $\begin{array}{l}\text { SDC and } \\
\text { Fed H.15 }\end{array}$ \\
\hline Subordinated & $\begin{array}{l}\text { Indicator equal to } 1 \text { when the firm has subordinated debt, and } 0 \\
\text { otherwise }\end{array}$ & Compustat \\
\hline Syndicate Size & Number of banks participating in the underwriting or loan syndicate & SDC \\
\hline Term Loan Dummy & Indicator equal to 1 when the loan is a term loan & SDC \\
\hline Term Spread & $\begin{array}{l}\text { Monthly difference between 10-year and 2-year CMT Treasury } \\
\text { yields }\end{array}$ & Fed H.15 \\
\hline Trad Private & $\begin{array}{l}\text { Indicator equal to } 1 \text { when the debt issue is a traditional private } \\
\text { placement }\end{array}$ & SDC \\
\hline
\end{tabular}




\section{Figure 1}

Location of urban, small city and rural counties and firms in the United States

This figure presents a map that distinguishes counties in the United States by urban proximity and identifies the location of debt issuing firms in our sample. As in Loughran and Schultz (2005), we categorize a county as urban if it is closer than 100 miles to any of the 10 most populated locations as per the 2000 Census. We define a county as rural those counties that are no closer than 100 miles from any of the top 49 U.S. metropolitan locations. We define the counties in between our rural and urban categorizations as small city counties. For readability's sake, we do not draw county limits except for rural areas and the outlining perimeters of the small city and urban areas. We then overlay in a darker shade the location of the counties in which we have at least one firm in our sample and delineate the boundaries of those counties.

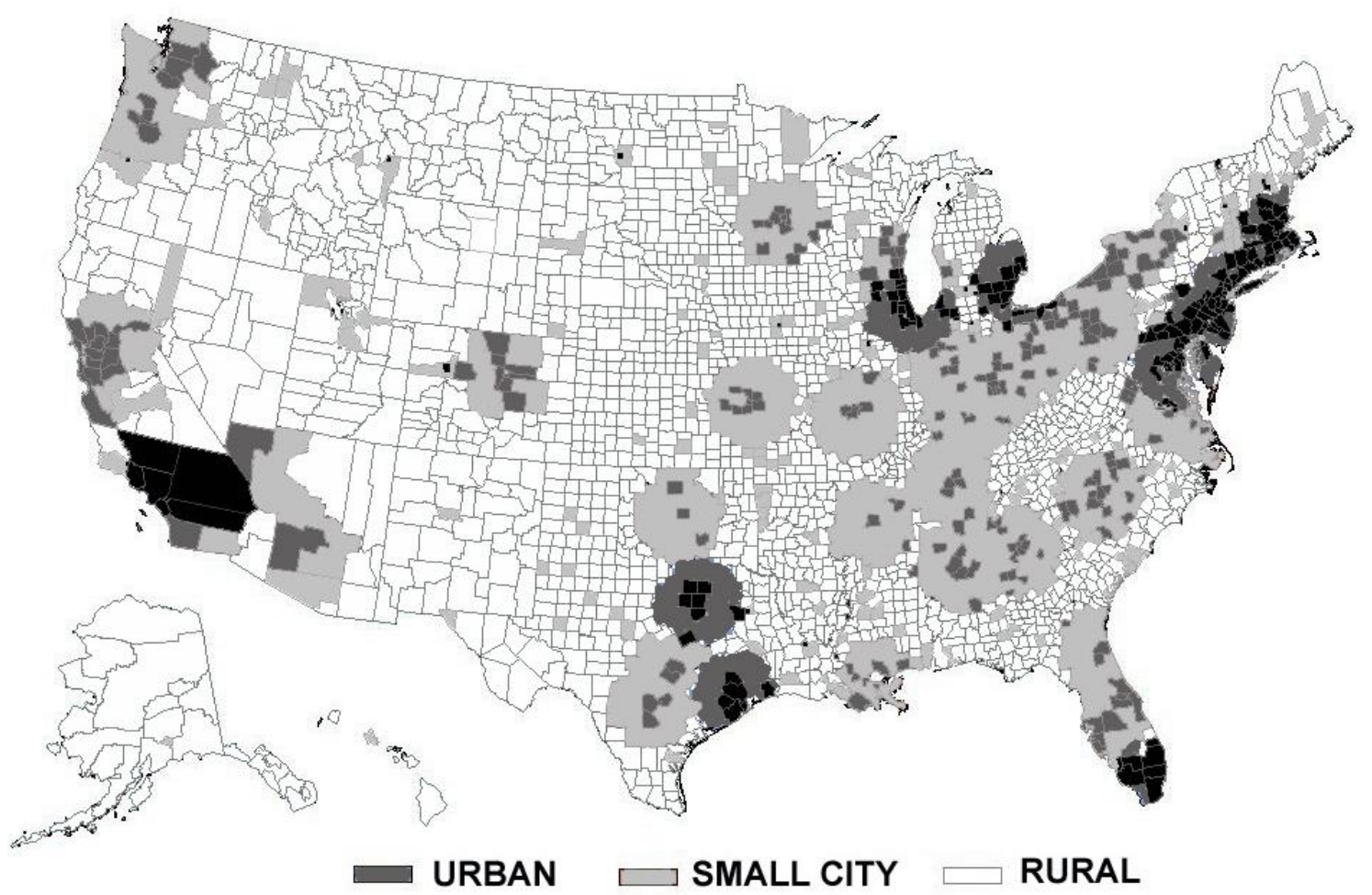


Table 1

Number of debt issues and type of debt for urban and rural firms

This table presents both the time-series and the choice distribution of our debt issue sample. We record the overall number of public and private deals after aggregation by quarter for both the urban and rural firms in our sample between 1996 and 2005. Panel A presents the distribution of debt issues between urban and rural firms by year. Panel B reports the number and proportion of different types of debt issued by firm location.

\begin{tabular}{lcccc}
\hline & urban & small city & & rural \\
\cline { 1 - 2 } & $\mathrm{N}$ & $\mathrm{N}$ & $\mathrm{N}$ \\
\hline $1996-2005$ & 7,560 & 4,941 & \\
1996 & 625 & 376 & 1,338 \\
1997 & 908 & 535 & 94 \\
1998 & 868 & 534 & 135 \\
1999 & 740 & 489 & 164 \\
2000 & 708 & 473 & 143 \\
2001 & 769 & 553 & 111 \\
2002 & 720 & 492 & 146 \\
2003 & 790 & 566 & 133 \\
2004 & 735 & 510 & 131 \\
2005 & 697 & 413 & 143 \\
\hline \multicolumn{2}{c}{ Panel B: Debt Choice } & 138 \\
\hline Public & $1,012(17 \%)$ & $785(16 \%)$ & $269(20 \%)$ \\
Bank Loan & $4,849(64 \%)$ & $3,288(67 \%)$ & $841(63 \%)$ \\
144 A & $1,307(13 \%)$ & $609(12 \%)$ & $150(11 \%)$ \\
Trad Private & $392(5 \%)$ & $259(5 \%)$ & $78(6 \%)$ \\
\hline
\end{tabular}


Table 2

Univariate statistics for firm and issue characteristics of rural and urban firms

This table presents the means, medians, number of observations t-values of the difference of the mean, and z-values of the Wilcoxon test for the medians for firm and issue characteristics of urban, small city, and rural firms. Panel A presents firm characteristics for firms in the entire Compustat universe for our sample period (19962005). Panel B presents issue characteristics for debt issues and loans reported by SDC - Global Issues during our sample period. We report the definition and source of all variables in the Appendix.

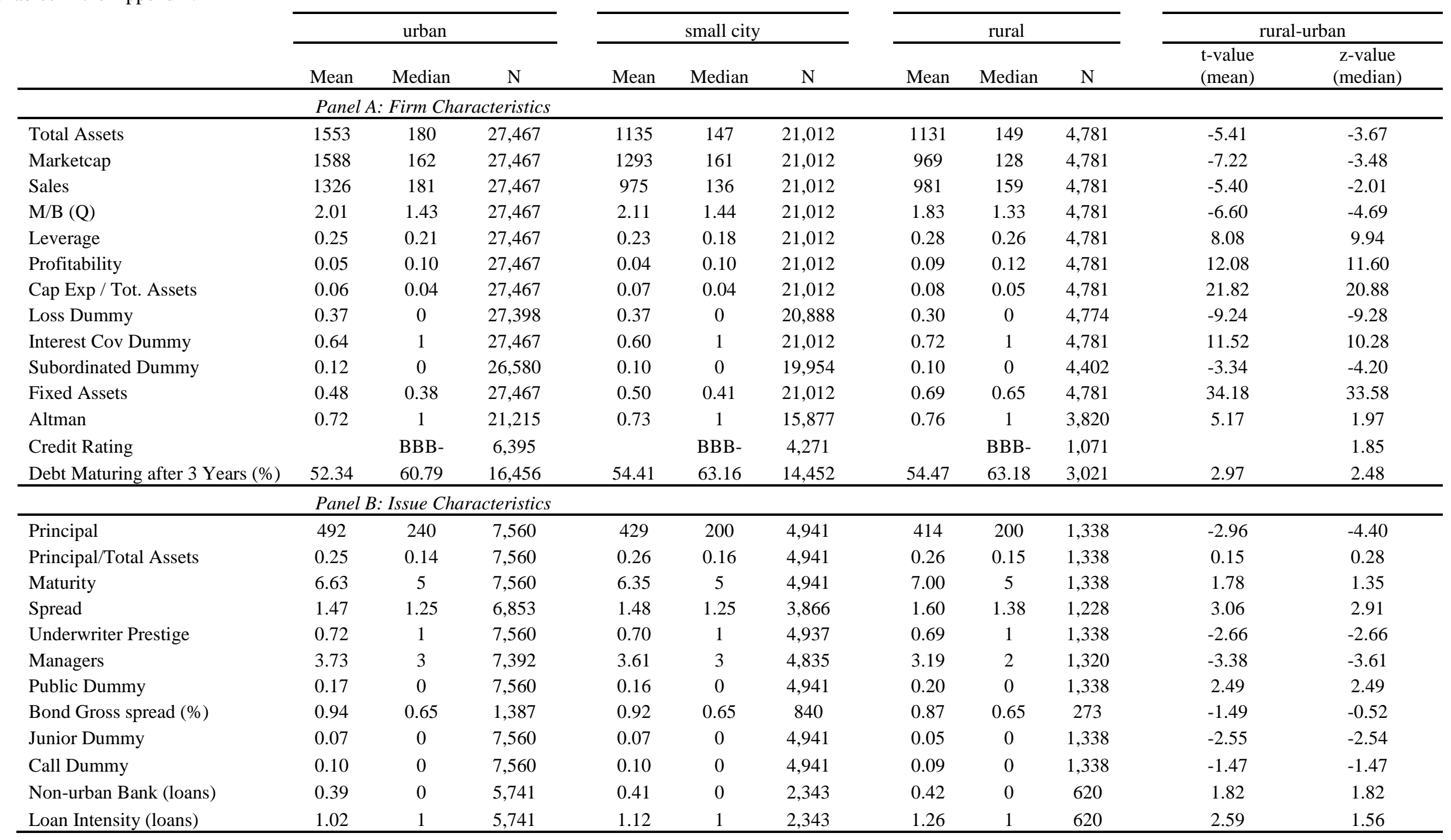




\section{Table 3}

\section{Corporate proximity to urban areas and the cost of debt}

This table presents the results of fixed-effect regressions (year and industry fixed effects) in which the dependent variables is the yield spread of public bonds and bank loans (percentage over the Treasury security of comparable maturity). The $\mathrm{p}$-values are reported in parenthesis and refer to robust standard errors adjusted for clustering at the firm level. The Appendix contains definitions of all variables and their sources.

\begin{tabular}{|c|c|c|c|c|c|c|c|c|}
\hline \multirow[b]{2}{*}{ Intercept } & \multicolumn{2}{|c|}{ (1) } & \multicolumn{2}{|c|}{ (2) } & \multicolumn{2}{|c|}{ (3) } & \multicolumn{2}{|c|}{ (4) } \\
\hline & 3.7441 & $(0.000)$ & 4.0519 & $(0.000)$ & 3.4089 & $(0.003)$ & 3.9298 & $(0.001)$ \\
\hline Rural & 0.0933 & $(0.020)$ & 0.0846 & $(0.032)$ & 0.0934 & $(0.020)$ & 0.0860 & $(0.030)$ \\
\hline Small City & 0.0027 & $(0.911)$ & -0.0091 & $(0.707)$ & -0.0028 & $(0.911)$ & -0.0137 & $(0.572)$ \\
\hline Bank Reputation & -0.2280 & $(0.000)$ & -0.2098 & $(0.000)$ & -0.1622 & $(0.000)$ & -0.2101 & $(0.000)$ \\
\hline $144 \mathrm{~A}$ & 0.8338 & $(0.000)$ & 0.8067 & $(0.000)$ & 0.8360 & $(0.000)$ & 0.8089 & $(0.000)$ \\
\hline Loan & -0.9872 & $(0.000)$ & -0.9857 & $(0.000)$ & -0.9912 & $(0.000)$ & -0.9906 & $(0.000)$ \\
\hline Trad. Private & 0.1614 & $(0.028)$ & 0.1002 & $(0.169)$ & 0.1599 & $(0.030)$ & 0.0984 & $(0.177)$ \\
\hline Lnassets & -0.2860 & $(0.000)$ & -0.2987 & $(0.000)$ & -0.2853 & $(0.000)$ & -0.2973 & $(0.000)$ \\
\hline Profitability & -0.7690 & $(0.000)$ & -0.7939 & $(0.000)$ & -0.7954 & $(0.000)$ & -0.7850 & $(0.000)$ \\
\hline Fixed Assets & -0.1743 & $(0.000)$ & -0.1680 & $(0.000)$ & -0.1482 & $(0.000)$ & -0.1424 & $(0.000)$ \\
\hline Loss & 0.7173 & $(0.000)$ & 0.7158 & $(0.000)$ & 0.7219 & $(0.000)$ & 0.7216 & $(0.000)$ \\
\hline Int Cov & 0.0000 & $(0.631)$ & 0.0000 & $(0.630)$ & 0.0000 & $(0.602)$ & 0.0000 & $(0.504)$ \\
\hline Subordinated Dummy & 0.1723 & $(0.000)$ & 0.1692 & $(0.000)$ & 0.1713 & $(0.000)$ & 0.1676 & $(0.000)$ \\
\hline Leverage & 1.1244 & $(0.000)$ & 1.0579 & $(0.000)$ & 1.1332 & $(0.000)$ & 1.0715 & $(0.000)$ \\
\hline Rating Residuals & -0.1524 & $(0.000)$ & -0.1509 & $(0.000)$ & -0.1520 & $(0.000)$ & -0.1510 & $(0.000)$ \\
\hline Lnprincipal & 0.0743 & $(0.000)$ & 0.0714 & $(0.000)$ & 0.0754 & $(0.002)$ & 0.0726 & $(0.000)$ \\
\hline Lnmaturity & -0.3733 & $(0.000)$ & -0.3191 & $(0.000)$ & -0.3740 & $(0.000)$ & -0.3190 & $(0.000)$ \\
\hline All Managers & -0.0040 & $(0.288)$ & -0.0048 & $(0.201)$ & -0.0039 & $(0.297)$ & -0.0047 & $(0.205)$ \\
\hline Call Dummy & 1.0727 & $(0.000)$ & 1.0226 & $(0.000)$ & 1.0740 & $(0.000)$ & 1.0240 & $(0.000)$ \\
\hline Junior Dummy & 0.2545 & $(0.000)$ & 0.2906 & $(0.000)$ & 0.2530 & $(0.000)$ & 0.2883 & $(0.000)$ \\
\hline Bank Term dummy & 0.6100 & $(0.000)$ & 0.6086 & $(0.000)$ & 0.6142 & $(0.000)$ & 0.6137 & $(0.000)$ \\
\hline Term Spread & -0.4174 & $(0.000)$ & -0.3956 & $(0.000)$ & -0.4183 & $(0.000)$ & -0.3942 & $(0.000)$ \\
\hline Credit Spread & 0.9408 & $(0.000)$ & 0.5567 & $(0.000)$ & 0.9391 & $(0.000)$ & 0.5542 & $(0.000)$ \\
\hline Rating Missing Dummy & 0.0294 & $(0.371)$ & 0.1060 & $(0.743)$ & 0.0251 & $(0.448)$ & 0.0071 & $(0.828)$ \\
\hline Year dummies & \multicolumn{2}{|c|}{ No } & \multicolumn{2}{|c|}{ Yes } & \multicolumn{2}{|c|}{ No } & \multicolumn{2}{|c|}{ Yes } \\
\hline Industry dummies & \multicolumn{2}{|c|}{ No } & \multicolumn{2}{|c|}{ No } & \multicolumn{2}{|c|}{ Yes } & \multicolumn{2}{|c|}{ Yes } \\
\hline $\mathrm{R} 2$ & \multicolumn{2}{|c|}{10,503} & \multicolumn{2}{|c|}{10,503} & \multicolumn{2}{|c|}{10,503} & \multicolumn{2}{|c|}{10,503} \\
\hline $\mathrm{N}$ & \multicolumn{2}{|c|}{0.51} & \multicolumn{2}{|c|}{0.53} & \multicolumn{2}{|c|}{0.51} & \multicolumn{2}{|c|}{0.53} \\
\hline
\end{tabular}


Table 4

Corporate proximity to urban areas and debt syndicate size

This table presents the results of Poisson regressions in which the dependent variable is the number of banks in the underwriting syndicate (Syndicate Size). The Appendix contains definitions of all independent variables and their sources. P-values relative to Chi-Square statistics are reported in parenthesis.

\begin{tabular}{|c|c|c|c|c|c|c|}
\hline \multirow[b]{2}{*}{ Intercept } & \multicolumn{2}{|c|}{$(1)$} & \multicolumn{2}{|c|}{ (2) } & \multicolumn{2}{|c|}{ (3) } \\
\hline & -1.1045 & $(0.119)$ & -1.0031 & $(0.157)$ & -0.6903 & $(0.491)$ \\
\hline Rural & -0.0316 & $(0.049)$ & -0.0356 & $(0.030)$ & -0.033 & $(0.050)$ \\
\hline Small City & 0.0146 & $(0.137)$ & 0.0146 & $(0.138)$ & 0.0127 & $(0.234)$ \\
\hline $144 \mathrm{~A}$ & -0.1173 & $(0.000)$ & -0.0983 & $(0.000)$ & -0.0982 & (0.000) \\
\hline Loan & -0.0644 & $(0.002)$ & -0.0406 & $(0.022)$ & -0.0645 & $(0.001)$ \\
\hline Trad. Private & -0.6595 & $(0.000)$ & -0.6339 & $(0.000)$ & -0.6282 & (0.000) \\
\hline Lnassets & 0.0098 & $(0.224)$ & -0.0120 & $(0.010)$ & -0.0068 & $(0.164)$ \\
\hline Lnprincipal & 0.3772 & $(0.000)$ & 0.3772 & $(0.000)$ & 0.3855 & (0.000) \\
\hline Lnmaturity & 0.0786 & $(0.000)$ & 0.0851 & $(0.000)$ & 0.0769 & $(0.000)$ \\
\hline Call Dummy & 0.0402 & $(0.030)$ & 0.0558 & $(0.003)$ & 0.0816 & $(0.000)$ \\
\hline Junior Dummy & 0.1082 & $(0.000)$ & 0.1166 & $(0.000)$ & 0.0660 & $(0.016)$ \\
\hline Bank Reputation & 0.2007 & $(0.000)$ & 0.1928 & $(0.000)$ & 0.2040 & $(0.000)$ \\
\hline Investment Grade & & & 0.1058 & $(0.000)$ & & \\
\hline Rating Residuals & & & & & 0.0063 & $(0.011)$ \\
\hline Rating Missing Dummy & & & -0.0394 & $(0.001)$ & -0.0824 & $(0.000)$ \\
\hline Profitability & & & & & -0.0499 & $(0.382)$ \\
\hline Fixed Assets & & & & & 0.0083 & $(0.536)$ \\
\hline Loss & & & & & -0.0962 & $(0.000)$ \\
\hline Int Cov & & & & & 0.0001 & $(0.163)$ \\
\hline Subordinated Dummy & & & & & 0.0495 & $(0.000)$ \\
\hline Leverage & & & & & -0.1148 & $(0.000)$ \\
\hline Year dummies & \multicolumn{2}{|c|}{ Yes } & \multicolumn{2}{|c|}{ Yes } & \multicolumn{2}{|c|}{ Yes } \\
\hline Industry dummies & \multicolumn{2}{|c|}{ Yes } & \multicolumn{2}{|c|}{ Yes } & \multicolumn{2}{|c|}{ Yes } \\
\hline $\mathrm{N}$ & \multicolumn{2}{|c|}{13,459} & \multicolumn{2}{|c|}{13,459} & \multicolumn{2}{|c|}{11,660} \\
\hline Pseudo R ${ }^{2}$ & \multicolumn{2}{|c|}{0.43} & \multicolumn{2}{|c|}{0.59} & \multicolumn{2}{|c|}{0.60} \\
\hline
\end{tabular}


Table 5

\section{Corporate proximity to urban areas and debt syndicate bank reputation}

This table presents the results of probit regressions in which the dependent variable is a binary variable equal to 1 if a reputable bank is the lead underwriter of an issue, and 0 otherwise (Bank Reputation). For issues with multiple lead underwriters, the dependent variable equals 1 if at least one of the co-lead banks is a reputable bank. The Appendix contains definitions of all independent variables and their sources. P-values relative to Chi-Square statistics are reported in parenthesis.

\begin{tabular}{|c|c|c|c|c|c|c|}
\hline \multirow[b]{2}{*}{ Intercept } & \multicolumn{2}{|c|}{$(1)$} & \multicolumn{2}{|c|}{ (2) } & \multicolumn{2}{|c|}{ (3) } \\
\hline & -6.2044 & $(0.997)$ & -5.9968 & (0.997) & -5.3926 & $(0.000)$ \\
\hline Rural & -0.0761 & $(0.077)$ & -0.0795 & $(0.065)$ & -0.1161 & $(0.016)$ \\
\hline Small City & -0.0127 & $(0.642)$ & -0.0099 & $(0.717)$ & -0.0307 & $(0.300)$ \\
\hline $144 \mathrm{~A}$ & -0.2353 & $(0.000)$ & -0.2035 & $(0.000)$ & -0.2543 & $(0.001)$ \\
\hline Loan & -0.3945 & $(0.000)$ & -0.3483 & $(0.000)$ & -0.3704 & $(0.000)$ \\
\hline Trad. Private & -0.7870 & $(0.000)$ & -0.7377 & $(0.000)$ & -0.7844 & $(0.000)$ \\
\hline Lnassets & 0.1472 & $(0.000)$ & 0.1116 & $(0.000)$ & 0.1363 & $(0.000)$ \\
\hline Profitability & 0.3024 & $(0.003)$ & 0.2845 & $(0.006)$ & 0.0884 & $(0.484)$ \\
\hline Lnprincipal & 0.3048 & $(0.000)$ & 0.3018 & $(0.000)$ & 0.2963 & $(0.000)$ \\
\hline Lnmaturity & -0.0569 & $(0.091)$ & -0.0530 & $(0.017)$ & -0.0463 & $(0.059)$ \\
\hline Call Dummy & -0.1517 & $(0.005)$ & -0.1254 & $(0.021)$ & -0.0724 & $(0.228)$ \\
\hline Junior Dummy & 0.0111 & $(0.8405)$ & 0.0198 & $(0.720)$ & 0.0191 & $(0.747)$ \\
\hline Investment Grade & & & 0.1570 & $(0.000)$ & & \\
\hline Rating Residuals & & & & & 0.0313 & $(0.000)$ \\
\hline Rating Missing Dummy & & & -0.0900 & $(0.003)$ & -0.1378 & $(0.000)$ \\
\hline Fixed Assets & & & & & 0.1314 & $(0.000)$ \\
\hline Loss & & & & & -0.0717 & $(0.072)$ \\
\hline Int Cov & & & & & -0.0001 & $(0.339)$ \\
\hline Subordinated Dummy & & & & & -0.0680 & $(0.064)$ \\
\hline Leverage & & & & & -0.2187 & $(0.003)$ \\
\hline Year dummies & \multicolumn{2}{|c|}{ Yes } & \multicolumn{2}{|c|}{ Yes } & \multicolumn{2}{|c|}{ Yes } \\
\hline Industry dummies & \multicolumn{2}{|c|}{ Yes } & \multicolumn{2}{|c|}{ Yes } & \multicolumn{2}{|c|}{ Yes } \\
\hline $\mathrm{N}$ & \multicolumn{2}{|c|}{13,735} & \multicolumn{2}{|c|}{13,735} & \multicolumn{2}{|c|}{11,897} \\
\hline Pseudo R ${ }^{2}$ & \multicolumn{2}{|c|}{0.15} & \multicolumn{2}{|c|}{0.29} & \multicolumn{2}{|c|}{0.42} \\
\hline
\end{tabular}




\section{Table 6}

\section{Corporate proximity to urban areas and relationship banking}

Panel A presents the results of Poisson regressions in which the dependent variable is the number of loans originated to the borrower by a specific bank in the role of agent over the last 3 years (Loan Intensity). Panel B presents the results of Probit regressions in which the dependent variable is an indicator equal to 1 when the lead lending bank of the loan is headquartered in a nonurban area, and 0 otherwise. (Non-Urban Bank). The Appendix contains definitions of all independent variables and their sources. P-values relative to Chi-Square statistics are reported in parenthesis.

Panel A: Loan Intensity

\begin{tabular}{|c|c|c|c|c|c|c|}
\hline & \multicolumn{2}{|c|}{ (1) } & \multicolumn{2}{|c|}{ (2) } & \multicolumn{2}{|c|}{ (3) } \\
\hline Intercept & -0.552 & $(0.582)$ & -0.268 & $(0.790)$ & -0.7616 & $(0.000)$ \\
\hline Rural & 0.1611 & $(0.000)$ & 0.1541 & $(0.000)$ & 0.162 & $(0.000)$ \\
\hline Small City & 0.0515 & $(0.045)$ & 0.051 & $(0.047)$ & 0.0752 & $(0.006)$ \\
\hline Lnassets & 0.1216 & $(0.000)$ & 0.1225 & $(0.000)$ & 0.0983 & $(0.000)$ \\
\hline Lnprincipal & 0.0907 & $(0.000)$ & 0.0786 & $(0.000)$ & 0.0816 & $(0.000)$ \\
\hline Lnmaturity & -0.1702 & $(0.000)$ & -0.2033 & $(0.000)$ & -0.2267 & $(0.000)$ \\
\hline Investment Grade & & & -0.1303 & $(0.000)$ & & \\
\hline Rating Residuals & & & & & 0.0106 & $(0.115)$ \\
\hline Rating Missing Dummy & & & -0.2042 & $(0.000)$ & -0.1383 & $(0.000)$ \\
\hline Profitability & & & & & 0.3187 & $(0.206)$ \\
\hline Fixed Assets & & & & & -0.0904 & $(0.007)$ \\
\hline Loss & & & & & 0.0736 & $(0.044)$ \\
\hline Int Cov & & & & & -0.001 & $(0.042)$ \\
\hline Subordinated Dummy & & & & & 0.0549 & $(0.101)$ \\
\hline Leverage & & & & & 0.5106 & $(0.000)$ \\
\hline Year dummies & \multicolumn{2}{|c|}{ Yes } & \multicolumn{2}{|c|}{ Yes } & \multicolumn{2}{|c|}{ Yes } \\
\hline Industry dummies & \multicolumn{2}{|c|}{ Yes } & \multicolumn{2}{|c|}{ Yes } & \multicolumn{2}{|c|}{ Yes } \\
\hline $\mathrm{N}$ & \multicolumn{2}{|c|}{6,332} & \multicolumn{2}{|c|}{6,332} & \multicolumn{2}{|c|}{5,614} \\
\hline Pseudo $\mathrm{R}^{2}$ & \multicolumn{2}{|c|}{0.36} & \multicolumn{2}{|c|}{0.53} & \multicolumn{2}{|c|}{0.55} \\
\hline
\end{tabular}

Panel B: Non-Urban Bank

\begin{tabular}{|c|c|c|c|c|c|c|}
\hline & \multicolumn{2}{|c|}{ (1) } & \multicolumn{2}{|c|}{ (2) } & \multicolumn{2}{|c|}{ (3) } \\
\hline Intercept & 6.7863 & $(0.997)$ & 6.6998 & $(0.997)$ & 6.7562 & $(0.998)$ \\
\hline Non-urban & 0.1565 & $(0.000)$ & 0.156 & $(0.000)$ & 0.1875 & $(0.000)$ \\
\hline Lnassets & -0.1611 & $(0.000)$ & -0.1601 & $(0.000)$ & -0.1330 & $(0.000)$ \\
\hline Lnprincipal & -0.0178 & $(0.331)$ & -0.0142 & $(0.440)$ & -0.0360 & $(0.074)$ \\
\hline Lnmaturity & -0.0123 & $(0.661)$ & -0.0027 & $(0.626)$ & 0.0031 & $(0.920)$ \\
\hline Investment Grade & & & 0.038 & $(0.388)$ & & \\
\hline Rating Residuals & & & & & -0.001 & $(0.909)$ \\
\hline Rating Missing Dummy & & & 0.0605 & $(0.090)$ & 0.0633 & $(0.152)$ \\
\hline Profitability & & & & & 0.0589 & $(0.715)$ \\
\hline Fixed Assets & & & & & -0.1150 & $(0.005)$ \\
\hline Loss & & & & & -0.1157 & $(0.014)$ \\
\hline Int Cov & & & & & 0.0001 & $(0.650)$ \\
\hline Subordinated Dummy & & & & & -0.0061 & $(0.888)$ \\
\hline Leverage & & & & & -0.3828 & $(0.000)$ \\
\hline Year dummies & \multicolumn{2}{|c|}{ Yes } & \multicolumn{2}{|c|}{ Yes } & \multicolumn{2}{|c|}{ Yes } \\
\hline Industry dummies & \multicolumn{2}{|c|}{ Yes } & \multicolumn{2}{|c|}{ Yes } & \multicolumn{2}{|c|}{ Yes } \\
\hline $\mathrm{N}$ & \multicolumn{2}{|c|}{7,753} & \multicolumn{2}{|c|}{7,753} & \multicolumn{2}{|c|}{6,923} \\
\hline Pseudo $\mathrm{R}^{2}$ & \multicolumn{2}{|c|}{0.25} & \multicolumn{2}{|c|}{0.44} & \multicolumn{2}{|c|}{0.49} \\
\hline
\end{tabular}


Table 7

Second-stage regressions coefficients explaining leverage and the percentage of total debt that matures in more than 3 years

The table shows the results of last-stage regressions of two simultaneous two-stage least squares regressions. The dependent variables of the two regressions are leverage and debt maturity. The Appendix defines all variables and presents their sources. P-values relative to White's (1980) heteroskedasticity consistent t-statistics are reported in parentheses.

\begin{tabular}{|c|c|c|c|c|}
\hline \multirow[b]{2}{*}{ Intercept } & \multicolumn{2}{|c|}{ (1) } & \multicolumn{2}{|c|}{ (2) } \\
\hline & 0.2644 & $(0.000)$ & 0.2200 & $(0.002)$ \\
\hline Debt Maturity & 0.4781 & $(0.000)$ & 0.4952 & $(0.000)$ \\
\hline Rural & -0.0426 & $(0.086)$ & -0.0383 & $(0.172)$ \\
\hline Small City & -0.0339 & $(0.089)$ & -0.0358 & $(0.155)$ \\
\hline Lnassets & -0.0411 & $(0.000)$ & -0.0444 & $(0.000)$ \\
\hline Profitability & -0.3935 & $(0.000)$ & -0.3899 & $(0.000)$ \\
\hline Fixed Assets & 0.1050 & $(0.000)$ & 0.1050 & $(0.000)$ \\
\hline Abnormal Earnings & 0.0001 & $(0.854)$ & 0.0001 & $(0.762)$ \\
\hline $\mathrm{Q}(\mathrm{M} / \mathrm{B})$ & 0.0047 & $(0.000)$ & 0.0047 & $(0.000)$ \\
\hline NOL & -0.0206 & $(0.115)$ & -0.0109 & $(0.132)$ \\
\hline ITC & -0.0253 & $(0.025)$ & -0.0289 & $(0.013)$ \\
\hline Regulated Dummy & 0.0256 & $(0.081)$ & 0.0389 & $(0.089)$ \\
\hline Year Dummies & \multicolumn{2}{|c|}{ No } & \multicolumn{2}{|c|}{ Yes } \\
\hline Industry Dummies & \multicolumn{2}{|c|}{ No } & \multicolumn{2}{|c|}{ Yes } \\
\hline $\mathrm{N}$ & \multicolumn{2}{|c|}{31,148} & \multicolumn{2}{|c|}{31,148} \\
\hline $\mathrm{R}^{2}$ & \multicolumn{2}{|c|}{0.65} & \multicolumn{2}{|c|}{0.68} \\
\hline
\end{tabular}

Panel B: Debt Maturity

\begin{tabular}{lcccc}
\hline & \multicolumn{2}{c}{$(1)$} & \multicolumn{2}{c}{$(2)$} \\
\hline Intercept & -0.0830 & $(0.000)$ & 0.0241 & $(0.551)$ \\
Leverage & 0.3878 & $(0.000)$ & 0.3713 & $(0.000)$ \\
Rural & 0.0007 & $(0.594)$ & 0.0004 & $(0.674)$ \\
Small City & 0.0119 & $(0.010)$ & 0.0136 & $(0.003)$ \\
Lnassets & 0.1022 & $(0.000)$ & 0.1008 & $(0.000)$ \\
Lnassets2 & -0.0044 & $(0.000)$ & -0.0041 & $(0.000)$ \\
Asset Maturity & 0.0001 & $(0.089)$ & 0.0001 & $(0.066)$ \\
Abnormal Earnings & -0.0001 & $(0.399)$ & -0.0001 & $(0.390)$ \\
Q (M/B) & -0.0002 & $(0.000)$ & -0.0002 & $(0.000)$ \\
Regulated Dummy & 0.0642 & $(0.000)$ & 0.0416 & $(0.002)$ \\
Rating Dummy & 0.1799 & $(0.000)$ & 0.1768 & $(0.000)$ \\
\hline Year Dummies & \multicolumn{3}{c}{ No } & \multicolumn{2}{c}{ Yes } \\
Industry Dummies & \multicolumn{3}{c}{ No } & \multicolumn{3}{c}{31,148} \\
\hline $\mathrm{N}$ & 31,148 & \multicolumn{3}{c}{0.20} \\
$\mathrm{R}^{2}$ & \multicolumn{3}{c}{0.18} & \multicolumn{3}{c}{} \\
\hline
\end{tabular}




\section{Table 8}

\section{Corporate proximity to urban areas and the cost of debt: Raw distance from large cities}

This table presents the results of fixed-effect regressions (year and industry fixed effects) in which the dependent variables is the yield spread of public bonds and bank loans (percentage over the Treasury security of comparable maturity). The $\mathrm{p}$-values are reported in parenthesis and refer to robust standard errors adjusted for clustering at the firm level. The Appendix contains definitions of all variables and their sources.

\begin{tabular}{|c|c|c|c|c|c|c|c|c|}
\hline \multirow[b]{2}{*}{ Intercept } & \multicolumn{2}{|c|}{ (1) } & \multicolumn{2}{|c|}{ (2) } & \multicolumn{2}{|c|}{ (3) } & \multicolumn{2}{|c|}{ (4) } \\
\hline & 3.7485 & $(0.000)$ & 4.0598 & $(0.000)$ & 3.449 & $(0.003)$ & 3.9707 & $(0.005)$ \\
\hline Distance & 0.1431 & $(0.011)$ & 0.1396 & $(0.020)$ & 0.1423 & $(0.011)$ & 0.1400 & $(0.017)$ \\
\hline Small City & -0.0600 & $(0.048)$ & -0.0655 & $(0.029)$ & -0.0660 & $(0.031)$ & -0.0718 & $(0.017)$ \\
\hline Bank Reputation & -0.1627 & $(0.000)$ & -0.2099 & $(0.000)$ & -0.1622 & $(0.000)$ & -0.2102 & $(0.000)$ \\
\hline $144 \mathrm{~A}$ & 0.8331 & $(0.000)$ & 0.8059 & $(0.000)$ & 0.8355 & $(0.000)$ & 0.8083 & $(0.000)$ \\
\hline Loan & -0.9882 & $(0.000)$ & -0.9870 & $(0.000)$ & -0.9924 & $(0.000)$ & -0.9920 & $(0.000)$ \\
\hline Trad. Private & 0.1616 & $(0.028)$ & 0.1003 & $(0.169)$ & 0.1601 & $(0.030)$ & 0.0984 & $(0.177)$ \\
\hline Lnassets & -0.2865 & $(0.000)$ & -0.2992 & $(0.000)$ & -0.2856 & $(0.000)$ & -0.2977 & $(0.000)$ \\
\hline Profitability & -0.7731 & $(0.000)$ & -0.7975 & $(0.000)$ & -0.7644 & $(0.000)$ & -0.7896 & $(0.000)$ \\
\hline Fixed Assets & -0.1727 & $(0.000)$ & -0.1664 & $(0.000)$ & -0.1462 & $(0.000)$ & -0.1406 & $(0.000)$ \\
\hline Loss & 0.7132 & $(0.000)$ & 0.7121 & $(0.000)$ & 0.7182 & $(0.000)$ & 0.7182 & $(0.000)$ \\
\hline Int Cov & 0.0000 & $(0.636)$ & 0.0000 & $(0.634)$ & 0.0000 & $(0.608)$ & 0.0000 & $(0.601)$ \\
\hline Subordinated Dummy & 0.1730 & $(0.000)$ & 0.1698 & $(0.000)$ & 0.1723 & $(0.000)$ & 0.1685 & $(0.000)$ \\
\hline Leverage & 1.1212 & $(0.000)$ & 1.0552 & $(0.000)$ & 1.1306 & $(0.000)$ & 1.0693 & $(0.000)$ \\
\hline Rating residuals & -0.1526 & $(0.000)$ & -0.1511 & $(0.000)$ & -0.1524 & $(0.000)$ & -0.1508 & $(0.000)$ \\
\hline Lnprincipal & 0.0744 & $(0.000)$ & 0.0715 & $(0.000)$ & 0.0755 & $(0.000)$ & 0.0728 & $(0.000)$ \\
\hline Lnmaturity & -0.3736 & $(0.000)$ & -0.3196 & $(0.000)$ & -0.3739 & $(0.000)$ & -0.3194 & $(0.000)$ \\
\hline All Managers & -0.0038 & $(0.313)$ & -0.0046 & $(0.218)$ & -0.0037 & $(0.324)$ & -0.0045 & $(0.225)$ \\
\hline Call Dummy & 1.0720 & $(0.000)$ & 1.0219 & $(0.000)$ & 1.0736 & $(0.000)$ & 1.0230 & $(0.000)$ \\
\hline Junior Dummy & 0.2541 & $(0.000)$ & 0.2902 & $(0.000)$ & 0.2524 & $(0.000)$ & 0.2879 & $(0.000)$ \\
\hline Bank Term dummy & 0.6093 & $(0.000)$ & 0.6080 & $(0.000)$ & 0.6138 & $(0.000)$ & 0.6133 & $(0.000)$ \\
\hline Term Spread & -0.4185 & $(0.000)$ & -0.3965 & $(0.000)$ & -0.4185 & $(0.000)$ & -0.3952 & $(0.000)$ \\
\hline Credit Spread & 0.9426 & $(0.000)$ & 0.5571 & $(0.000)$ & 0.9408 & $(0.000)$ & 0.5545 & $(0.000)$ \\
\hline Rating residuals dummy & 0.0278 & $(0.398)$ & 0.0092 & $(0.778)$ & 0.0237 & $(0.472)$ & 0.0059 & $(0.894)$ \\
\hline Year dummies & \multicolumn{2}{|c|}{ No } & \multicolumn{2}{|c|}{ Yes } & \multicolumn{2}{|c|}{ No } & \multicolumn{2}{|c|}{ Yes } \\
\hline Industry dummies & \multicolumn{2}{|c|}{ No } & \multicolumn{2}{|c|}{ No } & \multicolumn{2}{|c|}{ Yes } & \multicolumn{2}{|c|}{ Yes } \\
\hline $\mathrm{N}$ & \multicolumn{2}{|c|}{10,503} & \multicolumn{2}{|c|}{10,503} & \multicolumn{2}{|c|}{10,503} & \multicolumn{2}{|c|}{10,503} \\
\hline $\mathrm{R}^{2}$ & \multicolumn{2}{|c|}{0.49} & \multicolumn{2}{|c|}{0.52} & \multicolumn{2}{|c|}{0.50} & \multicolumn{2}{|c|}{0.52} \\
\hline
\end{tabular}

